\title{
Erratum to: Effect of Segment-Body Vibration on Strength Parameters
}

\author{
Ruben Tobias Goebel ${ }^{1 *}$, Heinz Kleinöder ${ }^{2}$, Zengyuan Yue ${ }^{3}$, Ranajay Ghosh ${ }^{4}$ and Joachim Mester ${ }^{2}$
}

Unfortunately, the original version of this article [1] contained an error in the author list. The name of the author Ranajay Ghosh was incorrectly spelt as Ranajay Gosh. The correct spelling is Ranajay Ghosh.

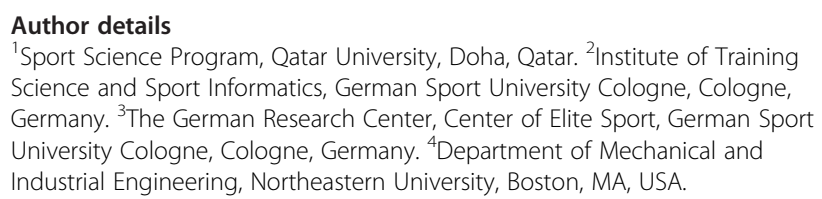

\section{Reference}

1. Goebel RT, Kleinöder H, Yue Z, Ghosh R, Mester J. Effect of segment-body vibration on strength parameters. Sports Medicine-Open. 2015;2:14.

\section{doi:10.1186/s40798-015-0028-6}

Cite this article as: Goebel et al:: Erratum to: Effect of Segment-Body

Vibration on Strength Parameters. Sports Medicine - Open 2015 1:14.

* Correspondence: ruben.goebel@qu.edu.qa

'Sport Science Program, Qatar University, Doha, Qatar

Full list of author information is available at the end of the article

\section{Submit your manuscript to a SpringerOpen ${ }^{\circ}$} journal and benefit from:

- Convenient online submission

- Rigorous peer review

- Immediate publication on acceptance

Open access: articles freely available online

High visibility within the field

Retaining the copyright to your article

Submit your next manuscript at $>$ springeropen.com

\section{Springer}

(c) 2015 Goebel et al. Open Access This article is distributed under the terms of the Creative Commons Attribution 4.0 International License (http://creativecommons.org/licenses/by/4.0/), which permits unrestricted use, distribution, and reproduction in any medium, provided you give appropriate credit to the original author(s) and the source, provide a link to the Creative Commons license, and indicate if changes were made. 